\title{
Construction materials flows and stocks in Paris region: an overview
}

\author{
Vincent Augiseau \\ Unilasalle Rennes - Ecole des Métiers de l'Environnement, Cyclann \\ E-mail address: vincent.augiseau@unilasalle.fr
}

\begin{abstract}
Mankind's most-used materials, construction materials pose major environmental challenges, mainly related to the increasing scarcity of certain primary resources. Using secondary resources, i.e. materials extracted from buildings and networks, is one response to these challenges. However, powerful constraints confront this kind of use. Paris region is studied as an example of an urban area in which secondary resources for construction offer strong potential. Possible courses of action to meet these challenges are outlined in the conclusion.
\end{abstract}

Keywords - construction materials, construction and demolition waste, circular economy, materials flows and stocks analysis, secondary resources

\section{INTRODUCTION}

\section{Global environmental challenges of the construction industry}

The construction industry is the source of significant material flows, from the extraction of natural resources, the production of materials and their use on construction sites, through to waste management. Secondary only to water in terms of mass, construction materials are mankind's most-used materials (IRP, 2018). Among these materials, non-metallic minerals and especially aggregates (sand and gravel) are the most used (Krausmann et al., 2009).

The construction, maintenance, repair and demolition of buildings and networks, along with some civil engineering work such as site leveling, result in outgoing flows of materials, commonly known as construction and demolition waste. In terms of mass, this is the primary source of solid waste produced by mankind (Krausmann et al., 2017). It comprises non-metallic minerals that stem from concrete, stone or brick structures as well as metal, wood, plastic and bituminous materials. It also comprises excavated materials, namely earth and minerals removed from a site during earthmoving operations.
Worldwide, only a third of construction and demolition waste in terms of mass, excluding excavated materials, is recycled as construction materials (ibid.). The materials derived from this recycling only represent a tenth of all the construction materials used (ibid.). Moreover, they are mainly used for purposes that are unsuited to their properties. For instance, recycled aggregates are predominantly used as backfill and for road building, uses which are the least demanding in terms of quality (see Hashimoto et al., 2007; Augiseau, 2017).

Flows of materials and waste are sources of environmental impacts and land-use conflicts. The production of construction materials requires a significant extraction of natural resources. These are, to a large extent, non-renewable and sometimes becoming scarce: at the global level, such as copper (Gordon et al., 2006) or at the local level, such as sand (Peduzzi, 2014). Moreover, mining operations, as well as the expansion of the built environment and the management of construction waste, result in land-use that temporarily or permanently reduces the capacity to produce or extract both renewable and non-renewable resources (Bringezu, 2002).

Besides contributing to the depletion of non-renewable resources, construction leads to pressure on the natural environment and interferes with human health. Mineral extraction transforms landscapes and negatively affects the fauna and flora of aquatic environments. This is particularly 
the case of the extraction of marine aggregates which leads to conflicts of use with fishing, as well as risks in terms of biodiversity, fishery resources and coastal erosion (Peduzzi, 2014).

The production of materials also creates air-borne emissions. Cement production is responsible for 5 to $6 \%$ of anthropogenic greenhouse gases worldwide (Mishra and Siddiqui, 2014). In addition, locally, air-borne emissions discharged by some cement plants lead to respiratory diseases (ibid.). Moreover, energy flows, also the source of environmental impacts, are associated with material flows (Pullen, 2000).

Figure 1 shows, in diagrammatic form, the flows of materials, energy, and emissions generated by the construction industry at a global scale, as well as the environmental impacts and land-use conflicts. According to Krausmann et al. (2017), it is considered that around a third of waste excluding excavated materials is recycled as materials, including all forms of recycling. In the absence of sources of estimates, the flows of excavated materials and emissions are not shown proportionately to the other material flows.

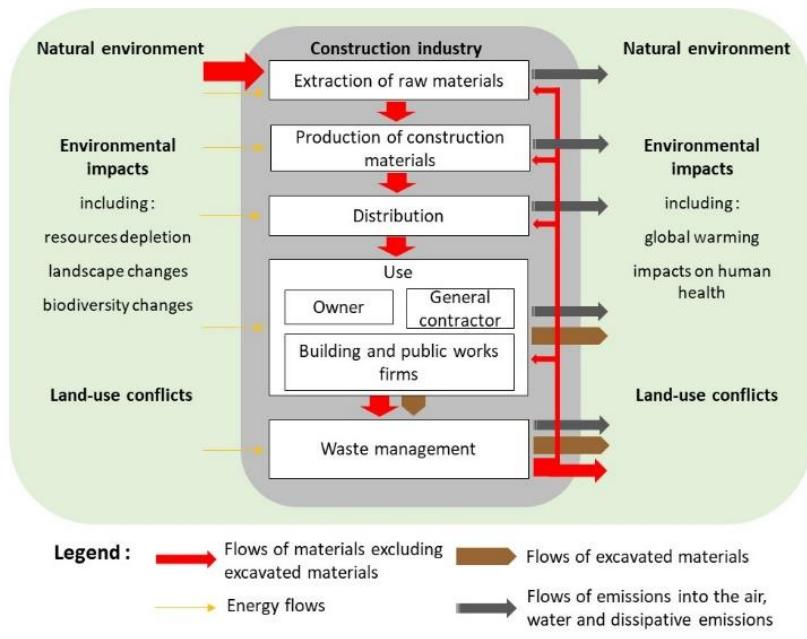

Figure 1. Diagrammatic representation of the flows, environmental impacts and land-use conflicts created by the construction industry at a global scale. Source: author

These global issues call for different levels of actions that can take place at different spatial scales. Among these is the implementation of coordinated action at a local scale between public and private stakeholders aiming at planning and managing the resources for construction. Such action requires detailed knowledge of the local environmental challenges to identify relevant courses of action. In this article, the case of Paris region (Ile-de-France) in France is studied using a method called materials flows and stocks analysis (MFSA). The method and data sources are presented first. Then the results of the flows and stocks analysis are shown. Then, in conclusion, possible courses of action within the framework of circular economy strategies are outlined.

\section{MATERIALS AND METHODS}

\section{Construction materials flows and stocks analysis}

Research on flows and stocks of construction materials and construction and demolition waste has expanded significantly since the end of the 1990s worldwide (Augiseau and Barles, 2017). This work has been undertaken in the scientific field of industrial ecology. One of its primary goal is to gain a greater awareness of the stocks of so-called secondary or anthropogenic resources. These stocks comprise materials accumulated by mankind. The materials found in buildings and networks make up the largest part of these stocks on a global scale (Krausmann et al., 2017). Part of these materials will be extracted from stocks in the future and could then either become unused waste or materials useful for new activities. The systematic use of resources from anthropogenic stocks is called urban mining (Brunner, 2011).

The study of stocks of secondary materials is based on an estimate of the mass of materials. The latter usually involves establishing a typology of the built works (buildings and networks). Based on models or field studies, a material content is assigned to each type of built work. Then, data regarding the built works are used to assign a type to each structure. These data are also used to estimate the dimensions of the buildings and networks (volumes, surfaces or lengths). These are then converted into mass, by using the specific material content (of volumes, surfaces or lengths) of each type of built work.

To this static study of the stocks, a dynamic analysis of the flows is added. This is based on the study of past and current flows of materials and waste to identify the factors affecting the flows. It also aims at forecasting them in a short or medium term. There are two main approaches for studying flows. The so-called top-down approach considers the inputs and outputs of materials in or from a socio-economic system (Augiseau and Barles, 2017). It uses statistics on the transport of goods, the extraction of minerals and the collection of wood and the production of waste. It may be cross-referenced with a so-called bottom-up approach which consists of studying a system from the inside and analyzing the flows process by process as in Baccini and Brunner (1991) This is the most used approach for forecasting flows.

\section{Paris region case study: methods and data}

In Paris region, the availability of resources for construction has increasingly become a focus of attention since the mid2000s. Management of these resources has given rise to studies carried out or overseen by the regional and interdepartmental environmental and energy directorate (DRIEE) and the Regional Council. These studies are undertaken as part of the implementation of the regional development blueprint (SDRIF) which sets out ambitious targets for constructing dwellings and business premises as well as developing the rail network by 2030 . They also aim to contribute to the establishment and then the application of new regional public policies: the regional quarries blueprint 
(coordinated by DRIEE) and the regional plan for preventing and managing waste (coordinated by the Regional Council). The text below provides a summary of the research work begun as part of a doctoral thesis funded by these two public authorities.

Paris region is studied through an analysis of stocks and flows of construction materials and construction and demolition waste in $2013^{1}$. The stocks studied include buildings, transport networks (road, rail and aerodrome runways) and energy and water networks (electricity, gas, heat and cold urban networks, potable and non-potable water, sewerage). The estimate relies on a typology and modeling of structures stemming from work conducted on the case of Orléans by Rouvrau et al. (2012). Two main sources of geolocated data were used to find out the characteristics and dimensions of the structures: the IGN's BD Topo and the tax records files (fichiers fonciers) of the Ministry of Finance.

Flows are studied using both top-down and bottom-up approaches. The top-down approach relies on the method published by Eurostat (2001) and adapted by CGDD/SDES (2014). The SitraM database on the transportation of goods was used to identify the inputs and outputs of materials per department. Data on the extraction of minerals from quarries and the harvesting of timber are known through statistics produced by the DRIEE (SIGIC database), UNICEM and Agreste (Ministry of Agriculture). The waste flows are known through the estimates produced by the Regional Council (Conseil Régional IdF, 2015) as well as the survey conducted by the regional economic construction unit (CERC, 2013). For 2013, a bottom-up approach is also used to supplement the flows analysis, by studying the types of construction activities that produce the flows.

\section{RESULTS}

\section{Paris region: primary resources not covering the consumption of materials}

Construction materials, in terms of mass, are the main materials used in Paris region. In 2013, the region uses 33.5 Mt of primary and secondary construction materials ${ }^{2}$, i.e. 2.8 $t$ per capita. Demand is highest for aggregates from primary (quarries) or secondary (recycling of mineral waste) resources. Aggregates are used in cement concrete, asphalt concrete, and road subbase courses. They are also used as backfill. The other non-metallic minerals make up the second-largest group of materials used. The consumption of metal, wood, plastics and other petroleum-based materials

\footnotetext{
${ }^{1}$ The most recent studies on waste flows in Paris region relate to 2015 and show results that are very close to those seen for 2013. The most recent statistics on the consumption of aggregates relate to 2017 and show results close to those of 2013. 2013 is studied here, since it is the year for which the most complete estimates have been made.
}

each respectively amount to less than $1 \%$ of total consumption.

The materials consumption of the region, although it fluctuates from year to year, remains of the same order in 2013 as in 1983. However, the region is confronted with increasing pressures regarding the extraction of primary resources. Indeed, the latter is faced with many obstacles, including the covering of deposits by urbanization, land-use conflicts and the price of land. Moreover, certain resources, and in particular alluvial aggregates, the sands used for concrete production, are being depleted and may no longer be extractable in less than fifty years (DRIRE Haute-Normandie, 1999).

A sharp decline in the extraction of primary aggregates and timber, which has been seen since 1983, is the result of these pressures. Therefore, the region resorts to growing imports of materials from other French regions and other countries. Imported materials are mainly derived from primary resources. They accounts for half of the direct entry of materials into the region in 2013. For aggregates, the proportion of imports in consumption increased from $24 \%$ in 1984 to $47 \%$ in 2015 (DRIEE et al., 2017).

\section{Strong potential for using secondary resources for construction}

The stocks of secondary resources for construction in Paris region represent a mass of $204 \mathrm{t}$ per capita in 2013: $146 \mathrm{t}$ per capita from buildings and $57 \mathrm{t}$ per capita from networks. These stocks include resources absent from the regional subsurface: around $40 \mathrm{Mt}$ of steel and iron, $0.5 \mathrm{Mt}$ of zinc and $0.3 \mathrm{Mt}$ of aluminum.

The extraction of secondary resources from these stocks is significant. It amounts to $12 \mathrm{Mt}$, or $1 \mathrm{t}$ per capita, which is close to the figure for the extraction of regional primary resources (minerals and timber): $15 \mathrm{Mt}$, i.e. $1.3 \mathrm{t}$ per capita The use of secondary resources and recycled aggregates produced from demolition waste, in particular, is also developing. However, it is still relatively limited since only $47 \%$ of the secondary resources extracted from stocks in 2013 were used in construction, mainly through recycling. Also, this use represents only $16 \%$ of the regional consumption of materials ${ }^{3}$. Moreover, this proportion only increased slightly between 2001 and 2013 and remained stable until 2015 (Augiseau and Barles, 2018).

Aggregates from recycled materials, which represent around $90 \%$ of the mass of secondary resources used, are very

\footnotetext{
${ }^{2}$ Domestic material consumption and local recycling according to the top-down approach.

${ }^{3}$ Domestic material consumption and local recycling according to the top-down approach.
} 
mainly used as backfill and for road building (DRIEE et al., 2017). These uses are less demanding in terms of quality than the production of concretes. However, the incorporation of aggregates from recycled materials in concrete is permitted since 2012 at rates that can be as high as $30 \%$ (NF EN 206$1 / \mathrm{CN}$ standard). As we saw in the previous point, the production of concrete is a significant consumption item and leads to high imports.

Besides the materials extracted from built stocks, most construction waste produced in Paris region in terms of mass, comprises excavated materials. The flows amount to $1.8 \mathrm{t}$ per capita. Only $13 \%$ of all the flows of excavated materials have been reused or recycled in construction, mainly for road building. The flows not used for construction are mainly used for quarry rehabilitation or disposed of in landfill sites.

\section{DISCUSSION}

The limitations of this work relate first of all to the assumptions and data used to quantify and locate the stocks. Some structures are not taken into account, including bridges and canals. The typology of built works could be refined to take better account of certain characteristics impacting material contents as traffic for road pavements. The assumptions adopted for estimating flows using the bottomup approach could be reinforced. Estimates must be validated against other data sources, including data from demolition professionals.

Furthermore, the results of this study conducted on a regional scale could be compared with local observation. The latter would make it possible to better characterize secondary resources, their extraction, and use, and to better understand the constraints weighing on these actions. Indeed, there are questions related to extraction, collection, separation, sorting and transformation techniques. At the local level, these technical issues are intrinsically linked to spatial, social and economic factors. This work was initiated as part of a study conducted with CitéSource and Néo-Eco (2019).

\section{CONClusions}

Our study highlighted the challenges that the construction industry faces in Paris region. It showed that on one hand, primary resources do not cover the consumption of materials and that on the other hand, the potential for using secondary resources for construction is strong. The limited use of the extracted secondary resources appears to be paradoxical given the growing problems of extracting regional primary resources. However, severe constraints or obstacles restrict the use of secondary resources in construction in France (Augiseau, 2020).

The concerted action of public authorities may allow a framework that is favorable to the use of secondary resources in construction. Local authorities can support the development of regional production infrastructure dedicated to sorting and recycling. Regional authorities can also encourage the use of secondary resources by linking urban planning to the planning of stocks and flows of materials. The creation of a spatialized database or cadastre of secondary resources (Brunner, 2011) is a possible course of action implemented by the city of Vienna, Austria (Kleemann et al., 2017). In Paris region, projects lead by the inter-municipal authorities of Plaine Commune and Est Ensemble aim to constitute such databases (Bellastock et al., 2018; CitéSource and Néo-Eco, 2019).

Besides, since secondary resources may only partially replace primary resources, strategies should aim at reducing upstream and downstream flows. Urban planning can encourage better occupancy and densification of built areas to contribute to reducing flows. Building permits and demolition permits are significant levers in regulating the production of flows of construction materials and construction and demolition waste.

These actions must be part of coherent circular economy strategies. A strategy in four prioritized steps is for example recommended for Amsterdam by Circle Economy et al. (2018). Firstly, reducing the demand for resources. Then identifying and exploiting local synergies that can satisfy these demands. Finally meeting the remaining demands with resources that have a lower impact and monitoring the results. Such a strategy may contribute to relocating construction and urban development activities within the region but, more importantly, to relocating these activities within the limits of the biosphere.

\section{OPEN ACCESS STATEMENT}

This article has been published under a Creative Commons Attribution 4.0 international license that provides immediate open access to its content on the principle that making research freely available to the public supports a greater global exchange of knowledge.

\section{REFERENCES}

AUGISEAU, V., BARLES, S. 2017. « Studying construction materials flows and stock: A review », Resources, Conservation and Recycling 123: 153-164.

DOI: $10.1016 /$ j.resconrec.2016.09.002

AUGISEAU, V., BARLES, B. 2018. Bilan de flux de matières de la région Ile-de-France en 2015. Rapport de recherche pour le Conseil régional d'Ile-de-France. $37 \mathrm{p}$.

AUGISEAU, V. 2020. «Utiliser les ressources secondaires de matériaux de construction : contraintes et pistes d'action pour des politiques territoriales ", Flux 116-117 : 21-36.

DOI : $\underline{10.3917 / \text { flux1.116.0026 }}$

BACCINI, P., BRUNNER, P. H. 1991. Metabolism of the Anthroposphere. Heidelberg, Springer-Verlag. 157 p.

BELLASTOCK, ALBERT \& COMPAGNIE, AUXILIA, RECOVERING, LE PHARES, CSTB, ENCORE HEUREUX, HALAGE, BTP CONSULTANTS. 2018. Bilan 
technique et stratégique. An 1 de la phase opérationnelle du projet Métabolisme urbain. 2017-2018. 89 p.

BRINGEZU, S. 2002. Towards sustainable resource management in the European Union.

BRUNNER, P. H. 2011. «Urban Mining, A Contribution to Reindustrializing the City », Journal of Industrial Ecology 15(3): 339-341.

DOI: $\underline{10.1111 / \mathrm{j} .1530-9290.2011 .00345 . \mathrm{x}}$

CERC ILE-DE-FRANCE. 2013. Production des déchets de chantiers en Ile-de-France et études connexes. 60 p.

CIRCLE ECONOMY, DGBC, METABOLIC, SGS SEARCH, REDEVCO FOUNDATION. 2018. A framework for circular buildings. Indicators for possible inclusion in BREEAM. 26 p.

CITÉSOURCE, NÉO-ECO. 2019. Rapport final du lot 1 pour Est Ensemble. Etude d'identification des gisements de matériaux et des filières de valorisation des déchets du BTP. $164 \mathrm{p}$.

COMMISSARIAT GENERAL AU DEVELOPPEMENT DURABLE, SERVICE DE L'OBSERVATION ET DES STATISTIQUES. 2014. «Comptabilité des flux de matières dans les régions et les départements. Guide méthodologique », Références. $111 \mathrm{p}$.

CONSEIL REGIONAL D'ILE-DE-FRANCE. 2015. Plan régional de prévention et de gestion des déchets issus des chantiers du bâtiment et des travaux publics. $256 \mathrm{p}$.

DRIEE, IAU ILE-DE-FRANCE, UNICEM. 2017. Granulats en Île-de-France. Panorama régional. $76 \mathrm{p}$.

DRIRE HAUTE-NORMANDIE. 1999. Schéma interrégional approvisionnement $d u$ Bassin parisien en matériaux de construction à l'horizon 2015. 112 p.

ELMQVIST, T., FRAGKIAS, M., GOODNESS, J., et al. (ed.). 2013. Urbanization, biodiversity and ecosystem services: challenges and opportunities: a global assessment, Springer.

DOI: $10.1007 / 978-94-007-7088-1$

EUROSTAT. 2001. Economy wide material flow accounts and balances with derived resource use indicators. A methodological guide. Luxembourg: Office for Official Publications of the European Communities. 85 p.
GORDON, R., BERTRAM, M., GRAEDEL, T. E. 2006. "Metal stocks and sustainability », Proceedings of the National Academy of Sciences 103(5): 1209-1214.

DOI: $10.1073 /$ pnas. 0509498103

IRP. 2018. The Weight of Cities: Resource Requirements of Future Urbanization. A Report by the International Resource Panel. United Nations Environment Programme, Nairobi, Kenya.

KLEEMANN, F., LEDERER, J., RECHBERGER, H., et al. 2017. « GIS-based Analysis of Vienna's Material Stock in Buildings », Journal of Industrial Ecology 21(2): 368-380. DOI: $\underline{10.1111 / \text { jiec. } 12446}$

KRAUSMANN, F., GINGRICH, S., EISENMENGER, N., et al. 2009. "Growth in global materials use, GDP and population during the 20th century », Ecological Economics 68(10): 2696-2705.

DOI: $10.1016 /$ j.ecolecon.2009.05.007

KRAUSMANN, F., WIEDENHOFER, D., LAUK, C., et al. 2017. «Global socioeconomic material stocks rise 23-fold over the 20th century and require half of annual resource use ", Proceedings of the National Academy of Sciences 114(8): 1880-1885.

DOI: $10.1073 /$ pnas. 1613773114

MISHRA, S., SIDDIQUI, N. A. (2014). A review on environmental and health impacts of cement manufacturing emissions. International journal of geology, agriculture and environmental sciences 2(3): 26-31.

OECD. 2018. Global Material Resources Outlook to $2060-$ Economic Drivers and Environmental Consequences. Highlights. 23 p.

PEDUZZI, P. 2014. Sand, rarer than one thinks. Environmental Development 2014(11): 208-218. DOI: $10.1016 /$ j.envdev.2014.04.001

PULLEN, S. F. (2000). Energy used in the construction and operation of houses. Architectural Science Review 43(2): 8794.

DOI : $\underline{10.1080 / 00038628.2000 .9697439}$

ROUVREAU, L., MICHEL, P., SERRAND, M., et al. 2012. Projet ANR ASURET - Analyse de flux de matière du secteur de la construction à l'échelle de l'ouvrage et du territoire (tâche 4.2) - Rapport BRGM/RP-61849-FR. 142 p. 